\title{
Evaluation of various training aspects of Agriclinics and Agribusiness Centres (ACABC's) Scheme in North Eastern Region
}

\author{
K.C. Prakash*, K. Ranaselva and E.P. Banuu Priya ${ }^{1}$ \\ Indian Institute of Plantation Management, Bengaluru (Karnataka) India \\ (Email: k.c.prakash26@gmail.com)
}

\begin{abstract}
India, a country being largely dependent on agriculture, realised the importance of the welfare of farming community and the graduates of agriculture, implemented the scheme ACABC in the year 2002 across the country. The scheme aims at utilizing the untapped potential of the knowledge possessed by the agri graduates to serve the partners of agriculture. The graduates are trained under the scheme and provided with credit facility. 34 per cent of agriprenuers react well to social media commination as source of advertising. Unemployment issue drives the need to build their own ventures and are more mature in attending the training sessions conducted by the "qualified personnel". Almost all particpants show positive alignment towards boarding and lodging facilities, also interestingly along with newspaper communication also the wi-fi provision are appreciated. There is scope for improvement in transportation, if provided by the nodal institutions. Overall the acceptance of the training is 53.22 per cent satisfied with ACABC training.
\end{abstract}

Key Words : Unemployment, Training, Respondents, Agriprenuers

View Point Article : Prakash, K.C., Ranaselva, K. and Banuu Priya, E.P. (2020). Evaluation of various training aspects of Agriclinics and Agribusiness Centres (ACABC's) Scheme in North Eastern Region. Internat. J. agric. Sci., 16 (2) : 187-192, DOI:10.15740/HAS/IJAS/16.2/ 187-192. Copyright@2020: Hind Agri-Horticultural Society.

Article History : Received : 08.03.2020; Revised : 05.05.2020; Accepted : 11.05.2020

\footnotetext{
* Author for correspondence :

${ }^{1}$ Tasty Bite Eatable Ltd., Pune (M.S.) India
} 